\title{
Asazi ukuthi iyozala nkomoni': Robert Mangaliso Sobukwe's historical imagination of the future
}

\begin{abstract}
This study will attempt to foreground the various underlying facets of Sobukwe's historical imagination and social philosophy through a close reading of his speeches and writings. It will be shown how Sobukwe's thought contains important observations for the study of identity, culture, history, and society; all concepts that are also of great importance to the field of psychosocial studies. The specific psychosocial dimension of Sobukwe's thought lies in an attention to the role of the historical imagination, what we can tentatively name a historical form of consciousness. This is a form of consciousness that stands in opposition to and looks beyond what is confined and prescribed as the current and its possibilities. The interrelationship between psychological and political liberation will be explored and expanded upon through a focus on the role that history plays in both. It will be shown how Sobukwe, together with other intellectuals and politicians associated with Pan-Africanism and African Nationalism, mobilised history as a theatre of struggle that tied together the realms of the psychological and the political in the quest for African liberation.
\end{abstract}

\section{Introduction}

"We, as individuals, are our history ... We don't leave history behind. History is the present, history is the future" - Amos Wilson (1993: 20)

\section{Terblanche Delport}

Department of

Philosophy,

Practical and

Systematic Theology,

University of South Africa,

Pretoria

delpopt@unisa.ac.za

\section{Keywords:}

Robert Mangaliso

Sobukwe, historical

consciousness, identity,

African Nationalism, conqueror/conquered, future politics

\footnotetext{
"What creature will come forth?" (Sobukwe, 1959/2013: 14)
} 
"As for the world, so for Afrika. The future of Africa will be what Africans make it" - Robert Mangaliso Sobukwe (1959/2013: 477)

This paper seeks to explore the existence of a tradition of political thought in South Africa that invokes a historical imagination of the future: a historical memory of liberation and resistance against colonial rule. It is my contention that this type of politics can be found in the writings and speeches of Robert Mangaliso Sobukwe and others who can be associated with an Africanist social philosophy of liberation (cf. Raboroko, 1960; Lembede, 1945/1996; Biko, 1978/2009). Sobukwe had a specific historical understanding of his present and the future of the country, and the Continent, different from the one that currently prevails. The necessity for the consideration of Sobukwe's thoughts and writings in the current conjuncture lies exactly in this historical imagination of a future liberated country, and Continent. A future that has been invoked clearly in recent times with, for example, the meteoric rise of the Economic Freedom Fighters (EFF) and its Student Command (EFFsC) as well as the resurgence of the Pan Africanist Student Movement of Azania (PASMA) and the massive student uprisings that rocked the country for a decolonised and free education. These movements and protests did not only invoke political concerns, but also more social, economic and indeed subjective concerns. The mass call for decolonisation and the return of land to the indigenous conquered people speaks to the return of dignity and full subjectivity to the individual that occupies a hostile lecture hall and survives in an inhospitable shack. The historical memory that tells of dispossession, violence, and subjugation, is still very much alive if one considers the material conditions of the majority of people in this country. The construction of identity and subjectivity in the present cannot be separated from its history, for as Amos Wilson (1993: 20) reminds us, "we, as individuals, are our history".

The psychosocial dimension of my argument can be found in the attention to the role of the historical imagination, what we can tentatively name a historical form of consciousness, in Sobukwe's thought. This is a form of consciousness that stands in opposition to and looks beyond what is confined and prescribed as the current and its possibilities. The interrelationship between psychological and political liberation will be illustrated through a focus on the role that history plays in both individual psychology and collective politics. It will be shown that Sobukwe's, and indeed other African theorists and politicians, association with Pan-Africanism and African Nationalism, mobilised history as a theatre of struggle that tied together the realms of the psychological and the political in the quest for African liberation. The ambition of this paper is therefore to foreground the various underlying facets of Sobukwe's historical imagination. This will include his envisioning of a different - even utopian - African future, and an attempt to demonstrate how each of these facets is 
never merely structural or political in nature, but is a facet of a broader aspect of, what we can term, political consciousness.

\section{A creature appears}

"Asazi Ukuthi lyozala Nkomoni? (What creature will come forth?)" (Sobukwe, 1959/2013: 14) This is a question posed by Robert Mangaliso Sobukwe at the occasion of the first annual meeting of the newly formed Pan Africanist Congress of Azania (PAC) in 1959, an organisation of which he was also the first president. Sobukwe asks this question in relation to the freedom of Africa, once it is free, what creature will Africa become? How would South Africa, or rather Azania, look when there is freedom? Sobukwe is here invoking an idea of an African existence and consciousness in the face of a growing white supremacist government in South Africa. Sobukwe's use of this metaphor also speaks to the fact that a form of African politics and mode of being has been consciously oppressed and subjugated. In order to project a future "Africanist Socialist Democracy" and "government of the Africans by the Africans, for the Africans" (Sobukwe, 1959/2013: 480), a historical imagination is therefore required. His is a historical imagination that would also enable a political consciousness of Pan-Africanism, a political consciousness based on a history of African resistance that can be critical of the present.

In an interview given by Sobukwe in the same year, he illustrates clearly how an understanding of the present, and the solution thereto, must be deeply linked with an understanding of history and an imagining of the future. Sobukwe states that the Africanists struggle is not to be found in an arbitrary political or historical date but rather in the history of Moshoeshoe and Chaka and these leaders' attempts at nation-building (1959/2013: cf 471). Sobukwe traces the inspiration for the Africanist movement long before colonialism, the consolidation of South Africa as a union in 1909, or the establishment of Apartheid in 1948. For Sobukwe, the locus of the struggle is not apartheid but the dispossession of land by an invading, conquering, class that turned the people living in Africa at that time into a class of conquered and dispossessed people. Consequently, it cannot be that South Africa belongs to all who live in it as it is so often claimed; it belongs to the African people since time immemorial. This is both a political and psychological reality related to a historical fact of dispossession and conquest.

The pre-history of the above speech by Sobukwe needs, however, to be contextualised within the rise of the Africanist element during the 1940s and 1950s in South Africa. The National Party was voted into power by a white minority in 1948 and the policy of apartheid started a process of legally codifying 300 years of colonial domination. In response to the growing apartheid machinery, the African National Congress (ANC) adopted a multi-racial and proto-human rights document in the form of Freedom 
Charter in 1955, a move that would see critique and dissent in from the Africanist faction within the movement (Seloane \& Mokoena, 2014: cf 1-2; 9). The Africanists were specifically opposed to the understanding of the current construction of society as well as the imagining of the vision of the post-liberation concept of the nation proposed in the Freedom Charter. There were competing theories of how the society has been, and continues to be, constructed and how it is to be critiqued, one from the side of the ANC "Charterists" (a term which to date carries derogative connotations in Africanist circles, arising from the assessment of the charter as a serious ethical compromise), and another from the Africanists. The idea that "South Africa belongs to all who live in it, both black and white" (Congress of the People, 1955/2013), being a particular point of contention.

Nkutsoeu Raboroko, NEC member of the PAC, writes in 1960 on the difference between the Freedom Charter and the PAC's Manifesto thus: "[t]he Manifesto of the Charterist Congress, the Kliptown Charter of 1955, speaks of and for the 'people of South Africa, black and white together'. The Africanist Congress, in the 1959 Pan Africanist manifesto, speaks of and for the 'African people', whom it regards as 'part of one African nation'. The basic literature of each body, therefore, provides the clue to its essential nature" (Raboroko, 1960: 25). The discrepancies between the PAC and the ANC social philosophy is clearly stated by Raboroko earlier in the same document as being a contention over the political interests represented in the Freedom Charter: "[t]he crucial issue today is whether the interests of the five million Europeans throughout Africa must continue to dominate over those of the two hundred and eighty million Africans, or whether the reverse process should obtain. This is an issue that no social philosophy pretending to have a solution for Africa's social problem can afford to gloss over" (Raboroko, 1960: 2). The social problem in Africa referred to by Raboroko is a historical one as much as it has implications in the present. A theory of the history of the present must thus be something that any Africanist social philosophy should contain if it is to offer a critical imagining of a future politics. The social philosophy that Raboroko refers to here must be one that has a way of making sense of the present and the past, but also of theorising, and imagining, a vision of a liberated future.

\section{The death of a European subject}

When the PAC was launched in 1959, it stated that the goal of the movement is "to unite and rally the African people into one national front on the basis of African nationalism and overthrow white, racist, settler colonial domination in order to establish and maintain the right of self-determination of African people for a unitary, non-racial democracy" (Quoted in Kondlo, 2009: 64). Within the core mission statement of the PAC we can clearly discern, as with Raboroko's article quoted above, an irreconcilable difference between political consciousness and political freedom. This we can term a 
praxis for liberation in that the goal of full liberation from "white, racist, settler colonial domination" cannot be separated from an Africanist "social philosophy" that puts the interest and welfare of "two hundred and eighty million Africans" as a central thesis of its unfoldment. In his speech delivered at the first annual meeting of the newly formed PAC, Sobukwe attempted to highlight and accentuate this praxis for liberation:

"We aim, politically, at government of the Africans by the Africans, for the Africans, with everybody who owes his only loyalty to Afrika and who is prepared to accept the democratic rule of an African majority being regarded as African ... Socially we aim at the full development of the human personality and a ruthless uprooting and outlawing of all forms or manifestations of the racial myth" (Sobukwe, 1959/2014: 480).

Sobukwe's argument is that the idea of the nation is an African one where the first step towards its full realisation is a systematic process of an individual and collective liberation from psychological, political, and economic, dependency. Sobukwe does not separate the "development of the human personality" from the political goals of an Africanist social philosophy and instead considers them in an interrelated way.

Sobukwe and the PAC's basic position and historical placement as contextualised above should also be read in relation to the overall developments in the anti-colonial struggles on the Continent. The era of the 1950s and 1960s saw the occurrence of several events on the Continent related to the larger anti-colonial struggle (Mazrui, 2005: cf 56-57; Ki-Zerbo, 2005: cf 84). Amongst these defining moments for African Nationalism was the All-African People's Congress held in 1958 in a newly independent Ghana with president Kwame Nkrumah at the helm. This congress was dominated by the debate on the escalation of the resistance to colonial rule to a more direct and violent struggle (Branch \& Mampilly, 2015: cf 38). The anti-colonial struggle was to escalate in intensity against occupying forces with Ghana the national vanguard of this Pan-African struggle. Joseph Ki-Zerbo (2005: 81) notes that the general climate in the 1950s was on where African Nationalism was "structurally programmed as a dialectic and antagonistic break with the realities, interests and values of the colonial nation-state whose intellectuals, drawn from the colonial school, had precisely to contribute to their permanent maintenance in power". This was also a time that saw a growing critique of Western values and colonial legacies through an assertion of African philosophies of self-reliance and humanity in the form of Kwame Nkrumah's African personality, Kenneth Kuanda's African humanism, and Julius Mwalimu Nyerere's Ujaama. There was thus a continued attempt by African leaders and theorists to understand the human being's relationship to its bigger society and also develop a philosophy of this society, a philosophical anthropology of this human. 
Within this attempt to re-define the African existence and humanness, African Nationalism continually presented a challenge to dominant Western theories of identity and culture. Amina Mama (1995: 34) argues that "[i]t was during the nationalist period that African redefinitions of what Nkrumah refers to as 'the African Personality' and what it means to be black were thrust into the international arena to fuel the existential and philosophical crises that the demise of colonialism provoked in the Western world and which ultimately led to the emergence of poststructuralism". African definitions and assertions of the human are historically parallel to the existential crises in the West, an existential crisis answered by post-structuralism and the decentring of the subject. Movements of African nationalism did not only function in the political sphere but brought together issues of theory and politics in the form of challenging dominant ideas of subjectivity, culture, and identity, that fuelled and aided the expansion of empire and the march of colonialism. African nationalism and theories of African personality "became a way of expressing the concern with celebrating the collective African past as articulating a collective will and vision for the future. Within it, personality was both a philosophical and political concept" (Mama, 1995: 34-35). Mama points out that the relationship between psychology and politics in the case of movements of African Nationalism intersected to such an extent that it posed fundamental questions not only to dominant European theories of political philosophy and philosophical anthropology, but also to psychology itself. According to Mama, psychology and dominant theories of behavioural and empiricist psychology "did not address the intellectual challenges that nationalist transformations engendered ... Psychologists did not address themselves to the way in which African nationalist discourses challenged European constructions of Africans" (Mama, 1995: 32). There is thus a looming question of what extent these African nationalist discourses have been incorporated into the critique of the current and the projection of the future.

The assertion of African humanism and individuality during the era of the struggle for independence went contrary to the dominant post-structuralist trends in Western thought that were theorising the shifting grounds of subjectivity and individuality related to super-structural power configurations and the slippages of concepts like truth, history and justice. As Mama points out above, the main reason we can make such a claim relates to the historical nature of the struggle for African liberation. African nationalism is an attempt to define what it means to be African, a human being second to none, and in the same move to re-define the idea of the human in total. This would have to cause a fundamental change in all aspects of human life and structural constructs like the state, law, and economy. The movements of African Nationalism on the Continent all attempted to think the human and affirm a human-ness against an existing, exclusionary, humanity, that was based on hundreds of years of colonial and white supremacist rule. This act of re-definition and re-signification is what 
Stuart Hall identifies as one of the most pertinent and lasting questions of another theorist of African liberation, Frantz Fanon (1961/2001). According to Hall (1997: 19), Fanon's project was to "consider the conditions for the production of a new kind of subject and the decolonisation of the mind as the necessary subjective conditions for the decolonisation of the world". Hall (1996: 19) continues to point out that to those theorists who consider history a "process without a subject" - a central thesis of Foucault's (2002) Archaeology of knowledge - will see this "attempt to constitute new forms of subjectivity and representation in some different register from that of the colonial relation" as "mere scribbling in the margins"

There are thus clear themes of history, subjectivity, culture, and identity, which repeat themselves thematically in the work and thought of Africanist thinkers across the Continent. These themes are also evident in the program of the PAC, another clear example of which can be seen in the Manifesto for the Africanist Movement (1959/2013: 484-485) and the guiding question of:

\footnotetext{
"how man shall live with his fellowman in fellowship; in harmony and peace. Man moves and has his being in a social environment. In the absence of social life the social question would fall away. Man's relation to his fellowman is determined by his primary needs. The social question, whose structural foundations are to be found in economic determinism, arises within the framework of social relations ... [the human is] a social being and not an economic animal. To live in harmony with his fellowman, man must recognise the primacy of the material interests of his fellowman, and must eliminate the tendency on his part to uphold his own interest at the expense of those of his fellowmen".
}

The Africanist manifesto here asserts a well-known southern African aphorism that re-iterates the primacy of the human as a social being and not merely an economic animal: feta kgomo o tshware motho (Ramose, 1999: cf 111-115). Directly translated, this aphorism speaks of the primacy of the human being over material things: "putting the preservation of human life through sharing before the relentless pursuit of profit" (Ramose, 1999: 115). This is an assertion of a way of life and living together that is based on a historical memory; a way of life that is used as a mode of resistance against the model of economic exploitation and instrumentalism associated with colonialism and apartheid.

\section{Blind consciousness, impotent action}

The abovementioned historical placement and theoretical contextualisation of African Nationalism allows us to consider it's positing of different ideas of history, subjectivity, culture, and identity as being a central aspect of its theoretical unfoldment and political 
project. The struggle against white supremacy and colonialism is therefore not merely a struggle on the terrain of the political, but also on the terrain of the social, the economical, the cultural, and the psychological. The clear distinction between theory and political praxis here becomes blurred since what is deemed traditionally as theoretical and intra-personal pursuits transforms into immediate political concerns and vice versa. It is within this understanding of African nationalism as tied to Pan-Africanism that we must seek to appreciate Sobukwe and his thoughts. More specifically, we need to understand how Sobukwe's thoughts contribute to the re-theorisation of African history and the assertion of an African personality. In Sobukwe, and other Africanist theories, there is a co-determining correlation between the macro-power structures that is white supremacy and colonialism and the micro-expressions of psychological power relations that it engenders.

In a piece authored by Sobukwe - but published under Potlako Leballo's name in 1957 in The Africanist as "The nature of the struggle today" - Sobukwe puts forth a series of definitional claims related to the social structures and mentalities that make-up the struggle against colonial oppression and the position of its participants. It is necessary to quote Sobukwe at length here:

"For the Africanists the struggle is both nationalist and democratic, in that it involves a restoration of the land to its rightful owners - the Africans - which fact immediately divides the combatants into the conquered and the conqueror, the invaded and the invader, the dispossessed and dispossessor. That is a national struggle. It has nothing to do with numbers and laws. It is a fact of history. And both sides are each held together by a common history and are, in the struggle, carrying out the task imposed by history. That task is, for the whites, the maintenance and retention of the spoils passed on to them by their forefathers and, for the Africans, the overthrow of the foreign yoke and the reclamation of 'the land of our fathers'" (Sobukwe, 1957/2013: 465).

Sobukwe is here presenting us with an analysis related to the social relations between people in South Arica in 1957. The point Sobukwe is making is that the social relations in South Africa are those of domination and oppression within which the different parties must be considered as either the conqueror or the conquered. The categorisation of South Africa into conqueror and conquered has to be understood in relation to the attempted formulation of an Africanist approach to the struggle against colonialism in South Africa. These categories posited by Sobukwe are related to both material and psychological positionality. The white, conquering class, is in both a material and psychologically dominant position to that of the indigenous conquered people. It is here where we again see a clear trace of Sobukwe's thought in the work of other important

PINS [Psychology in Society] 50, 2016|42 
South African liberation thinkers: Anton Muziwakhe Lembede, Ashley Peter Mda, and Jordan Kush Ngubane and their formulation of the South African struggle in the ANC Youth League's 1944 Manifesto as "[t]he contact of the White race with the Black race has resulted in the emergence of a set of conflicting living conditions and outlooks on life which seriously hamper South Africa's progress to nationhood" (Lembede, Mda \& Ngubane, 1944/1996); as well as Steve Bantu Biko's (1978/2009: 53) conceptualisation Black Consciousness as "the realisation by the black man of the need to rally together with his brothers around the cause of their operation - the blackness of their skin - and to operate as a group in order to rid themselves of the shackles that bind them to perpetual servitude". Sobukwe is, like Biko after him and Lembede and Mda before him, identifying a mechanism of domination and oppression that has formed and moulded South African society into these different political identities. This formulation of Sobukwe forces a contrary reading of the famous opening clause of the Freedom Charter by stating clearly that South Africa cannot automatically belong to all who live in it. The categories of conqueror and conquered carries with it a value judgement related to the legitimacy of the claim to rightful ownership of land by a white, conquering class. Related to this point is also the refusal of using merely Marxist categories of class analysis to analyse the mechanism of domination and oppression in South African society. Sobukwe is therefore not only critiquing a dominant trend in the Charterist movement of the time, but is also attempting to posit an Africanist analysis of South African social relations.

This argument furthermore sees the locus of the struggle against white supremacy or the continuation of a colonial conquest and not merely capitalism and apartheid. The mechanism of domination in South Africa cannot be reduced to capitalist exploitation without taking into account the social categories of conqueror and conquered. Although there is a possibility of reductionism in this binary formulation by Sobukwe, it forces an understanding of South Africa as a place where one cultural identity and history is accorded more social value than another. The formulation of conqueror and conquered is one that equates the bigger structure of domination of colonialism and white supremacy to the specific social identities that individuals perform. It is a way to understand colonialism and white supremacy as a historical movement that still structures social relations and power positions. The inter-relationship between white supremacy and colonialism is based on these social constructs. Amina Mama (1995: 17) defines this interrelationship by reminding us that

"[i]t is worth pointing out that enslavement and colonisation did not only materially exploit and politically subordinate African resources and ways of life but at the same time transformed and subjected Africans to the imaginings and caprices of imperial culture and psychology. Colonisation was carried out by an expansionist regime that owed its success to both military and mercantile power, which it ruthlessly deployed 
in the practice of trade, conquest and enslavement. So it was that the imperial powers were able to assert, maintain and reproduce white supremacy across the globe. White supremacy can thus be conceptualised as a set of discourses and practices that subjugated non-European people and cast them in the position of subjected Others, while it advanced the interests of European nations".

This is an important aspect that is again discernible in the current political realities of South Africa: the continued existence of the country along the fractured lines of mental and social constructs related to white supremacy's arrangement of society into conqueror and conquered, a relationality that again came to the fore in the recent student and worker protests at specifically the University of Pretoria and the University of the Free State. It is exactly for this reason that the relevance of Sobukwe's call for both a nationalist and a democratic struggle is still relevant and pertinent.

The nationalist struggle is what enables the Africanists to see the social structure as stratifying its participants as conquerors and conquered, invader and invaded. This formulation by Sobukwe does not see apartheid as an exceptional mode of oppression but rather as part of a historical fact of colonial conquest. Colonisation has as its main goal the turning of a geographical area into an extension of the metropolis: "Colonialism ... can be thought of as a duplication and a fulfilment of the power of Western discourses on human varieties" (Mudimbe, 1988:29). Colonialism is thus a possession by force, and transformation of, space and territory. The conqueror is the colonialist and the conquered are those that have been, and for Sobukwe continue to be, colonised. Sobukwe insists that the conquered peoples must "either go under or exist as a nation. We are convinced that the struggle is between the conquerors and the vanquished and there can be no compromise nor surrender on our part, nor can we agree to go 50's with the oppressor in Afrika" (Sobukwe, 1957/2013: 469). Sobukwe realises the inherent connection of political consciousness with that of political action. Sobukwe is attempting to drive home the realisation of the condition of the conquered, and that the conquered people should unite against the conquering forces. It is only at that stage when people can name their oppression that they become conscious of the un-natural condition of their situation. The nationalist aspect of the struggle is this political consciousness aspect that can mobilise people not as oppressed workers but indigenous conquered people.

The nationalist struggle, being for Sobukwe a fact of history, is something that acts as a guiding principle from which to articulate a position regarding the struggle against apartheid; it is a mode of politics and theory that can be responsive to the African experience and mode of being-black-in-the-world (cf Manganyi, 1973). Where the "democratic struggle is a recognition of numbers, a National struggle is a struggle for the recognition of heritage" (Sobukwe, 1957/2013: 465). We can thus argue that there

PINS [Psychology in Society] 50, $2016 \mid \mathbf{4 4}$ 
has been an over-reliance on the gains of a democratic struggle that only focuses on the number of Africans able to partake in the decision-making processes of an already existing government. This is a reduction of democracy to a method of decision-making. To understand the democratic and national struggle as interconnected follows more closely an understanding of democracy as the power of a group to not only partake in the decision making processes of the government but also to establish a certain form of society. Democracy understood in the latter sense is a form of power generated by a political community in order to form certain social institutions. To let grow "the tree rooted in African soil, nourished with waters from the rivers of Africa" (Sobukwe, 1959/2013: 480) requires more than the mere entrance into an already existing democratic structure of decision-making, it requires the re-constitution of this democratic process based on a historical imagination of the future. Following our emphasis on political consciousness and political action, we can thus suggest that Sobukwe formulates the nationalist aspect of the struggle as the political consciousness element and the democratic aspect as the political action element. It is the interrelationship of these two that leads to what we have referred to earlier as an Africanist political praxis: political consciousness without action is blind and political action without consciousness is impotent.

\section{As for the world, so for Africa}

"We have chosen African Nationalism because of its deep human significance; because of its inevitability and necessity to world progress. World civilization will not be complete until the African has made his full contribution" (Sobukwe, 1949: 10)

Sobukwe's conceptual construct of conqueror and conquered thus speaks to a historical understanding of a struggle against global white supremacy and its attempted destruction of the history of the conquered people. The formulation of what is needed to bring about liberation for the African people is deeply rooted in a theory of the present social order as well as the historical situation that gave rise to it. Successive colonial regimes attempted to erase any type of historical memory of the conquered people and subject them to the caprices and want of colonial rule and European history. African Nationalism as a theory of liberation consequently has to engage with this history. Although there is a remarkable danger in attempting to view modern Africa through the lens of ancient Africa or attempting a return to a pre-colonial time, the distinction between modern and ancient is in itself a problematic formulation (Okere, 1996). There is a continuation in the existence of African history and culture, a continuation and connection that most Africanist leaders not only saw but also insisted on asserting against the violent and systematic doubt levelled against its existence. This is an integral element of any Africanist's understanding of history and historiography as has already been pointed out above. The tradition of liberation that is invoked by Sobukwe - and 
Lembede, Mda, Fanon, and Biko - is one that includes the wars of resistance fought by a people that were in the process of being conquered. Sobukwe's claim of a history of an anti-imperial struggle as a source for African politics appeals to an idea of nationalism as a social philosophy and not merely as linked with the formation of a nation-state. In a speech in 1959, Sobukwe emphasises this when he argues that

"Moshoeshoe brought together the scattered remnants of various African tribes and moulded them into a patriotic Sotho tribe, he was engaged in nation-building. Similarly Chaka's wars whereby he sought to establish a single authority in place of many tribal authorities of Natal, were, we say, steps in the direction of nationbuilding. In the Cape the House of Gcaleka was recognized as the Paramount authority. There is no doubt that the pressure of social and economic conditions would in time have given rise to the Union of these territories" (1959/2013: 471).

The most orthodox theory of nationalism holds that the existence of nations in Europe develops at the same time as capitalism (Nzongola-Ntalaja, 1987: cf 43). This argument excludes the possibility of nationalism in Africa prior to colonial conquest. According to this argument, pre-colonial Africa cannot have nations because capitalism is only brought with conquest. When the colonial settlers first made contact with the continent there was an acceptance that the land was terra nullius (land belonging to no one) and res nullius (nobody's property), with the people occupying the land filius nullius (son of nobody) (Pheko, 1990: of 1; 62). This tripartite thesis also does not allow the acknowledgment of political formations and modes of politics prior to colonial conquest. The indigenous people of the continent were not seen as necessary to engage with but rather only to force into a foreign system of cultural and economic bondage as labourers and slaves. The colonialists also needed the indigenous people, and imported slaves from other conquered territories, to be able to commence in their program of transforming their "new" territory into a station to serve the colony. This resulted in the production of Africa as an archive where the data set (including people) was observed, considered, and systematized into an already accepted European history (cf. Mudimbe, 1988, above). There was thus no history that was not colonial history or a history in the process of being colonised. For the colony to be transformed into the metropole, everything that exists in the colony must be either transformed or destroyed. Any type of knowledge that was not from the metropole was thus also to be transformed or destroyed.

Africa was - and perhaps still is - considered as the ground for resource exploitation in order to build European Nations. When political movements arose that attempted to assert National identity and use it as a mode of resistance, they were supressed with violence or discredited politically and theoretically. Nzongola-Ntalaja (1987: 44) argues that "[i]n pre-colonial Africa there were nations ... corresponding to social formations 
made up of closely related lineages or other kinship groups unified by a core cultural tradition and a relatively durable politico-administrative structure". The effect of colonialism and conquest on these forms of nationality was also much more complex than merely disrupting the process of nation building:

"On the one hand, the imposition of colonial rule resulted in the fading away of a large number of pre-colonial nations.... On the other hand, colonialism united different African nationalities and peoples under a single territorial and institutional framework, widened their social space as a result of greater inter-ethnic interaction through the institutions and practices of the colonial system, and thus created a common historical experience of economic exploitation, political and administrative oppression, and cultural oppression" (Nzongola-Ntalaja, 1987: 46).

Nzongola-Ntalaja's argument acts as a helpful heuristic device with which to read the theory of history and the nation formulated by Sobukwe under the conqueror/ conquered distinction. In arguing for the assertion and confirmation of an African heritage and history, Sobukwe emphasises the existence of a historical praxis different to the one brought by the conqueror; it becomes a historical praxis that asserts identity and history as modes of resistance (Wamba-dia-Wamba, 1992; Ramose, 1999). We also need to read the appeal to anti-imperialist kings within this same frame of reference: these kings are an example of conquered people acting in opposition to the conquering forces. Acting in opposition against a foreign system of value and politics has to be understood as asserting a political formation and mode of politics and social living that is different to the one being opposed. It is not opposition in the sense of mere reaction, but informed by the disruptive experience of living under the yoke of colonial subjugation and positing a way to live and be governed differently: "[w]e must have faith and devotion to duty with courage and a determination to defend our cherished ideals that Africa is for the Africans, that the Cause of Africa must triumph, that we must remember Africa first, that African nationhood must be achieved irrespective of whatever odds are facing us, and that our right to determine the destiny of our Fatherland is an inherent one." (Sobukwe, 1957/2013: 468). This form of being governed is the reference to a mode of politics that existed prior to its disruption by colonial conquest. Sobukwe sees Africanism as at once a historical praxis invoking a way of living differently as well as a political movement of anti-imperialism; a form of political consciousness as well as an actionable political programmatic. The political argument of restoration and restitution was not seen as separate or in fact qualitatively different from the struggle against epistemicide and a new conception of the social. Because colonisation in southern Africa is based on the tripartite thesis of terra nullius, res nullius, and filius nullius, the assertion of a mode of politics of the African nation questions exactly this fundamental argument. 
It is also the abolishment of this white supremacist argument that becomes an integral aspect of the possibility of a future liberated Africa and, as Biko reminds us, "a true humanity". The insistence of the liberation of Africa, and the new creature that must emerge, is therefore also an insistence on the changing of the world-order "because African and humanity are inseparable ... On the liberation of Africa lies the liberation of the whole world. The future of the world lies with the oppressed and the Africans are the most oppressed people on earth" (Sobukwe, 1949: 11). The creature that will come forth is thus not only a liberated and independent Africa, but also a world-order that does not build itself on the exploitation and underdevelopment of Africa; a liberated world-order for all oppressed people. Sobukwe's social philosophy, as discussed above, is one that attempts to give us the conceptual and social constructs of conqueror and conquered as the mechanism of domination with which to understand the present, and the past, of the country. These are also concepts that can allow the construction of a future: if these terms continue to exist in ways that structure the sphere of social praxis as well as its economic and material conditions, then there is still a critique to be made.

\section{The end}

Robert Mangaliso Sobukwe forms part of a tradition of Africanist leaders and thinkers who saw in the political emancipation of Africa the need for a radical historical praxis. These thinkers considered the political argument of restoration and restitution as inseparable from the struggle against epistemicide. The politics proposed by the Africanist tradition is one that is not only based on resisting a current mode of oppression, but rather positing a completely different imagining of the social and its past, present, and future. This imagining of the social is one that does not accept the descriptive condition of the present and its possibilities as an option for a political praxis; the imagining of the social is one that asserts a political praxis, a normative model of action that moves beyond the available descriptive possibilities for action.

It was Otto von Bismarck who once remarked, ,Die Politik ist die Lehre vom Möglichen” (von Bismarck 1895: 248). Mostly translated in political textbooks as "politics is the art of the possible", its literal translation rings closer to "politics is the logic/theory of the possible". Von Bismarck's remark has become one of the most visibly manifested characteristics of politics: possibility, feasibility, and negotiability. A politics that can move in compromised spaces, a politics that can negotiate. Politics in South Africa specifically has become this politics of the possible, where the possible is created inside well-rehearsed myths and symbols such as the rainbow nation, the constitution, a liberated country, post-apartheid. This concept of the possible was also constructed as historical memory, assisted by the Truth and Reconciliation Commission, that made Apartheid the sole purveyor of evil in the country known as South Africa. The history of struggles against colonialism on this southern point of Africa that started in 1510 was 
conveniently forgotten. The lack of historical memory that animates this politics of the possible also lacks a historical imagination of the future. A historical imagination of the future is a way of thinking a future possibility based on the current historical juncture. It is an imagination of a possible future that is rooted in a historical praxis. Politics as the logic/theory of the possible is exactly one that takes for granted the existing foundations of the political, one that is based on the global construction of white supremacy and its specific local manifestations. This is also a politics that can easily be identified with the ANC. From the forming of the SANNC through to the Defiance Campaign and Freedom Charter to the most recent political power sharing tactic called by some "negotiations", the SANNC/ANC have proved themselves to be a party that sees politics as the art of the possible: the possibility to be included through petitions and the possibility to negotiate a power sharing platform. This pragmatic approach to politics can perhaps explain the ANC's continued success as a parliamentary political party in the ways in which they negotiate themselves into positions of possibility and at times ethically questionable feasibility.

It is my argument in this paper that in opposition to the negotiated pragmatism of the ANC, individuals like Raboroko, Sobukwe, Biko, and the Africanist tradition, shows us a politics that has to be a logic of the impossible. In the face of white supremacy and an increasing repressive governmental apparatus, the assertion of an African historical praxis and mode of politics is exactly what is impossible. A historical imagination of the future is a politics as the theory of the impossible since it is able to think a political future that is not yet real. Politics as the theory of the impossible is this realisation of that which cannot yet be thought: the true liberation of Africa and the assertion of an African historical praxis. This is not achievable through the application of a pragmatic politics because, as Nkoane (1968: 36) points out, the conquered people have been "subjected to conditions that all but dwarfed mental development, had been beaten into submission to the point of resignation and acceptance of their lot as irredeemable" and the need "[t]o break this stranglehold was as much a sociological as a political need". A liberatory politics had to be able to prove liberation as a possibility in an impossible situation. An affirmation of the existence of a history of being governed differently was important to break this political and sociological stranglehold. A social philosophy of the present, the past, and the future is the necessary and sufficient condition for a liberatory politics to pronounce itself. It is a historical imagination of the future, a politics as the theory of the impossible, which is able to break the stranglehold mentioned by Nkoane. To think the impossible is to think the liberation of the conquered people of Africa. In the words of a young Sobukwe (1949: 9): "Watch our movements keenly and if you see any signs of 'broad mindedness' or 'reasonableness' in us, or if you hear us talk of practical experience as a modifier of man's views. Denounce us as traitors to Africa". 


\section{References}

Biko, S (2009) I write what I like. Johannesburg: Picador (1978).

Congress of the People (1955/2013) The freedom charter, in Karis T G and Gerhardt G M (eds) From protest to challenge: A Documentary history of African politics in South Africa, 1882-1990. Volume 3: Challenge and violence, 1953-1964. Auckland Park: Jacana.

Foucault, M (2002) The archaeology of knowledge. (Trans. Sheridan-Smith, A M) London: Routledge (1969-French).

Fanon, $F$ (2001) The wretched of the earth. (Trans. Farrington, C) London: Penguin (1952-French).

Hall, S (1996) The after-life of Frantz Fanon: Why Fanon? Why now? Why Black Skins, White Masks?, in Read, A (ed) The fact of blackness: Frantz Fanon and visual representation. Seattle: Bay Press

Ki-Zerbo, J (2005) African intellectuals, nationalism and pan-Africanism: A testimony, in Mkandawire, $T$ (ed) African intellectuals: Rethinking politics, language, gender and development. Dakar: CODESRIA Books.

Lembede, A M (1945/1996) Some basic principles of African Nationalism, in Edgar, RE and Msumza, L K (eds) Freedom in our lifetime: The collected writings of Anton Muziwakhe Lembede. Ohio: Ohio University Press.

Lembede, A M (1945/1996) Know thyself, in Edgar, R E and Msumza, L K (eds) Freedom in our lifetime: The collected writings of Anton Muziwakhe Lembede. Ohio: Ohio University Press.

Lembede, A M, Mda A P\& Ngubane, J K (1944/1996) Congress Youth League manifesto, in Edgar, RE and Msumza, LK (eds) Freedom in our lifetime: The collected writings of Anton Muziwakhe Lembede. Ohio: Ohio University Press.

Mama, A (1995) Beyond the masks: Race, gender and subjectivity. London: Routledge.

Manganyi, N C (1973) Being-black-in-the-world. Johannesburg: Sprocas/Ravan Press. 
Mazrui, A (2005) Pan-Africanism and the intellectuals: Rise, decline, and revival, in Mkandawire, $T$ (ed) African intellectuals: Rethinking politics, language, gender and development. Dakar: CODESRIA Books.

Mudimbe, VY (1988) The invention of Africa: Gnosis, philosophy, and the order of knowledge. Indiana: Indiana University Press.

Nzongola-Ntalaja, C (1987) Revolution and counter-revolution in Africa: Essays in contemporary politics. London: Zed Books.

Okere, T (1996) African culture: The past and present as an indivisible whole, in Okere T (ed) Identity and change. Washington: Paideia.

Pan Africanist Congress of Azania (1959/2013) Manifesto for the Africanist movement, in Karis T G and Gerhardt G M (eds.) From protest to challenge: A Documentary history of African politics in South Africa, 1882-1990. Volume 3: Challenge and violence, 1953-1964. Auckland Park: Jacana.

Pheko, S E M (1990) South Africa: Betrayal of a colonised people. Issues of international human rights law. Johannesburg: Skotaville Publishers.

Pheko, S E M (1994) The land is ours: The political legacy of Mangaliso Sobukwe. New York: Pheko \& Associates.

Raboroko P N (1960) The Africanist case. Africa South, 3(4), 24-32.

Raboroko, P N (1959/2014) Manifesto for the Africanist movement in Karis T G \& Gerhardt G M (eds) From protest to challenge: A documentary history of African politics in South Africa, 1882-1990. Volume 3: Challenge and violence, 1953-1964. Auckland Park: Jacana.

Ramose, M B (1999) African philosophy through Ubuntu. Zimbabwe: Mond Books and Publishers.

Ramose, M B (2003) I doubt, therefore African philosophy exists. South African Journal of Philosophy, 22(2), 113-127

Ramose, M B (2013) An African perspective on the strategic significance of HIV/AIDS for Africa and her diaspora, in Ramose M B (ed) Hegel's twilight: Liber amicorum discipulorumque pro Heinz Kimmerle. Amsterdam : Rodopi. 
Seleoane, M \& Mokoena, B (2014) Reflections on the freedom charter 1955. Pretoria: Ears Publishing.

Sobukwe, R M (1949) Address on behalf of the graduating class at Fort-Hare college. Speeches of Mangaliso Sobukwe from 1949-1959 and other documents of the Pan-Africanist Congress of Azania. New York: The PAC Observer Mission to the United Nations.

Sobukwe, R M (1957/2013) The nature of the struggle today, in Karis T G and Gerhardt $\mathrm{G} M$ (eds) From protest to challenge: A Documentary history of African politics in South Africa, 1882-1990. Volume 3: Challenge and violence, 1953-1964. Auckland Park: Jacana.

Sobukwe, R M (1959/2013) Future of the Africanist movement: Questions and answers by Robert Sobukwe, in Karis T G and Gerhardt G M (eds) From protest to challenge: A Documentary history of African politics in South Africa, 1882-1990. Volume 3: Challenge and violence, 1953-1964. Auckland Park: Jacana.

Sobukwe, R M (1959/2013) Opening address to PAC inaugural convention in Karis T G and Gerhardt G M (eds) From protest to challenge: A Documentary history of African politics in South Africa, 1882-1990. Volume 3: Challenge and violence, 1953-1964. Auckland Park: Jacana.

Wamba-dia-Wamba, E (1992) Beyond elite politics of democracy in Africa. Quest, 6(1), 28-44.

Wilson, A (1993) The falsification of Afrikan consciousness: Eurocentric history, psychiatry and the politics of white supremacy. New York: Afrikan World InfoSystems.

Von Bismarck, O (1895) Interview with Friedrich Meyer von Waldeck of the St. Petersburgische Zeitung on 11 August 1867, in Fürst Bismarck: neue tischgespräche und Interviews, Vol. 1. Stuttgart: Deutsche Verlags-Ansta. 